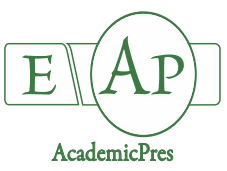

Angelopoulou F et al. $(2020)$
Notulae Botanicae Horti Agrobotanici Cluj-Napoca 48(4):2153-2166
DOI: $10.15835 /$ nbha48412056
Research Article

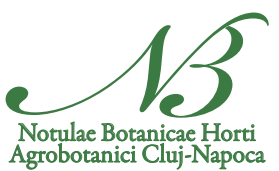

\title{
Tillage intensity and compost application effects on organically grown camelina productivity, seed and oil quality
}

\author{
Foteini ANGELOPOULOU ${ }^{1 *}$, Eleni TSIPLAKOU ${ }^{2}$, \\ Dimitrios BILALIS ${ }^{1}$
}

\author{
${ }^{1}$ Agricultural University of Athens, Department of Crop Science, 75 Iera Odos Street, WA 11855, Athens, \\ Greece; bilalis@aua.gr (*corresponding author); fangelo@aua.gr \\ ${ }^{2}$ Agricultural University of Athens, Department of Animal Science and Aquaculture, 75 Iera Odos Street, WA 11855 Athens, \\ Greece; eltsiplakou@aua.gr
}

\begin{abstract}
The importance of Camelina sativa has lessened substantially over the last half century, however its unique oil composition and the beneficial agronomic attributes with regard to sustainable agriculture have recently reignited interest in this oilseed crop. Notwithstanding the great interest in camelina, the potential to be cultivated organically has not received prominent attention from researchers. The objective of this study was to evaluate the response of organic camelina to different tillage systems and compost types, based on differences in yield parameters, oil content, seed crude protein and fatty acid profile. The field experiments, conducted during the 2014, 2015 and 2016 growing seasons, were laid out in a split plot design with three replicates, two main plots (conventional tillage and minimum tillage) and three sub-plots (vermicompost, compost, unamended control). It is consequential from the results that the effect of the type of organic amendment was highly significant on camelina's productivity. Particularly, compost treatment resulted in higher seed and oil yield (1132 and $446 \mathrm{~kg} \mathrm{ha}^{-1}$, respectively) compared to the vermicompost (682 and $269 \mathrm{~kg} \mathrm{ha}^{-1}$, respectively) and the unamended control (554 and $220 \mathrm{~kg} \mathrm{ha}^{-1}$, respectively). Regarding the fatty acid profile, both organic amendments increased linoleic and palmitic acids, while they presented disparate effects on a-linolenic acid. Furthermore, tillage system influenced significantly only thousand seeds weight, protein content and gondoic acid, enabling the use of reduced tillage to be comparably effective on organically grown camelina performance. Further experimentation is needed to match crop needs with the appropriate cropping techniques in order to ensure an effective organic cultivation.
\end{abstract}

Keywords: Camelina; compost; oil content; organic; tillage system; yield

\section{Introduction}

Camelina (Camelina sativa L. Crantz) is an annual oilseed plant belonging to the Cruciferae family, native to Mediterranean region and Central Asia (Falasca et al., 2014). The name camelina derived from Greek words chamai (dwarf) and linion (flax) and archaeological evidence suggests its cultivation in Europe dating back to the Bronze Age (Bouby, 1998). Cultivation decreased during the Middle Ages was gradually displaced 
by higher-yielding crops such as rapeseed, but was still reported as late as the middle of the 20th century (Zubr, 1997).

In recent years, is being considered as a novel alternative oilseed crop with distinguishing features and a unique and versatile oil profile that could make it a competitive contender against the dominant global vegetable oils, for nutritional and industrial applications (Chaturvedi et al., 2017). Oil content of camelina seeds can range from 30\% to 49\% (Zubr, 2003; Vollmann et al., 2007; Vollmann and Eynck, 2015) and oil yield is estimated to be 106 to $907 \mathrm{~L} \mathrm{ha}^{-1}$ which is significantly higher than soybean (347 to $562 \mathrm{~L} \mathrm{ha}^{-1}$ ) and sunflower (505 to $750 \mathrm{~L} \mathrm{ha}^{-1}$ ) (Moser, 2010). The major part of camelina fatty acid composition consists of unsaturated fatty acids $(\sim 90 \%)$, with a percentage of alpha-linolenic acid about $35 \%(18: 3 ; \mathrm{n}-3)$ and linolenic acid (18:2;n6) about $15 \%$ which make camelina oil unique among the common vegetable oils, such as soy oil, sunflower oil, canola oil and olive oil (Dharavath et al., 2016). Parallel with the increased concern for camelina oil occurred the exceptional interest for the crop. Competitive edges in agronomic performance of camelina make its cultivation for oil production in temperate regions favorable, primarily due to its very short growing season (85 to 100 days), tolerance to drought and low temperatures, compatibility with cover crops, adequate resistance to common cruciferous pests and pathogens and its ability to be grown in marginal lands and environmentally friendly with low fertilizer and pesticide requirements (Putnam et al., 1993; Vollmann et al., 2007). The aforementioned agrotechnical benefits make $C$. sativa an ideal crop that can be easily adapted to sustainable agricultural practices and systems, such as organic farming (Akk and Ilumäe, 2005).

As a low input crop camelina is reported to have modest nutritional requirements for nitrogen $(\mathrm{N})$, phosphorus $(\mathrm{P})$, potassium $(\mathrm{K})$, and sulfur $(\mathrm{S})$, nonetheless nutrient management is a crucial factor in camelina growing technology as it affects growth, yield and seed quality (Waraich et al., 2013; Obour et al., 2015). Substantial quantities of nutrient elements and notable contents of organic matter, which can contribute to support crop productivity, agricultural sustainability and improve soil quality, can be provided by addition of organic amendments (Diacono and Montemurro, 2010). The application of organic amendments is common in organic farming systems and include wastes or byproducts from agricultural, industrial, and municipal operations such as animal manures, compost and green manures (Goss et al., 2013). Several studies have focused on the response of different oilseeds crops to the use of organic soil amendments and their beneficial effects on crop yield and seed quality (Pasricha et al., 1988; Ogbonna and Umar-Shaaba, 2011, Khan et al., 2016), whereas limited information exists concerning the response of camelina to organic fertilization. Regardless fertilization, tillage operations play an important role in sustainable farming systems. Tillage reduction and organic amendments input are two common practices which are considered essential for soil organic matter content, carbon sequestration, nutrient and water availability, microbial biomass and activity under Mediterranean climate (Laudicina et al., 2010). Recently, a shift toward in conservation tillage systems, including no-tillage and minimum tillage, in contrast to conventional tillage has occurred due to the fact that reduces water and soil erosion, labor requirements and saves fuel costs (Blevins and Frye, 1993). According to Keshavarz-Afshar et al. $(2015,2016)$ camelina tended to yield $26 \%$ more in conventional tillage than no-tillage system but the energy input was 5 and $8 \%$ lower in no-tillage system at the environmental condition of Montana. However, limited data is available (Angelopoulou et al., 2020) regarding the performance of camelina under different tillage systems in combination with organic amendments application in Mediterranean conditions. The

objective of this study was to quantify single and combined effects of different compost inputs and tillage systems on yield, seed and oil properties of organically grown camelina.

\section{Materials and Methods}

Site specification

The field trials were conducted in 2014, 2015 and 2016 growing seasons at Tripoli region ( $37^{\circ} 30^{\prime} 30^{\prime \prime}$ $\mathrm{N}, 22^{\circ} 22^{\prime} 30^{\prime \prime} \mathrm{E} ; 660 \mathrm{~m}$ altitude), central Peloponnese, Southern Greece. The soil at the experimental site was 
characterized as Clay Loam with low organic matter, total N, Olsen P and extractable $\mathrm{K}^{+}$(Table 1). Soil samples were collected to a depth of $0-25 \mathrm{~cm}$, then were air-dried and sieved to $2 \mathrm{~mm}$ prior to analysis. Soil $\mathrm{pH}$ and soluble salts were determined in a 1:2 saturated paste soil extract (Bates, 1964). Organic carbon was determined by the Walkey-Black method (Walkey and Black, 1934) and the total nitrogen was determined by the Kjeldahl method (Bremmer, 1960). Exchangeable cations were determined using an ammonium acetate extraction method (Thomas, 1982).

Table 1. Pre-seeding selected soil $(0-25 \mathrm{~cm})$ physical and chemical properties at the experimental site

\begin{tabular}{|c|c|c|c|}
\hline Soil characteristics & 2014 & 2015 & 2016 \\
\hline Sand \% & 32.4 & 33.6 & 30.2 \\
\hline Silt \% & 38.1 & 37.8 & 38.3 \\
\hline Clay \% & 29.5 & 28.6 & 31.5 \\
\hline $\mathrm{pH}$ & 6.9 & 6.6 & 6.5 \\
\hline Total organic carbon $(\%)$ & 1.9 & 1.5 & 1.6 \\
\hline Electrical conductivity $(\mu \mathrm{S} / \mathrm{cm})$ & 63.5 & 58.2 & 61.8 \\
\hline Total Nitrogen $(\%)$ & 0.11 & 0.10 & 0.10 \\
\hline P-Olsen $\left(\mathrm{mg} \mathrm{kg}^{-1}\right)$ & 10.8 & 10.7 & 10.8 \\
\hline $\mathrm{K}\left(\mathrm{mg} \mathrm{kg}^{-1}\right)$ & 106.1 & 100.5 & 98.3 \\
\hline $\mathrm{Mg}\left(\mathrm{mg} \mathrm{kg}^{-1}\right)$ & 195.3 & 182.5 & 175.8 \\
\hline
\end{tabular}

The average monthly precipitation and air temperature during the period of the experimental trial (April-July) for three consecutive growing seasons, in relation to the long-term averages (1957-2010) are presented in Figure 1. The cumulative growing degree days (GDD) were calculated based on the maximum daily air temperature (Tmax) and the minimum daily air temperature (Tmin) for each growing season and the period between sowing and harvest time (Table 2 ) as follows:

$$
G D D=\sum \llbracket(\operatorname{Tmax}-\mathrm{Tmin} / 2)-\text { Tbase } \rrbracket
$$

For camelina, a base temperature (Tbase) of $5^{\circ} \mathrm{C}$ were used for the calculation (Gesch, 2014; Sintim et al., 2016).

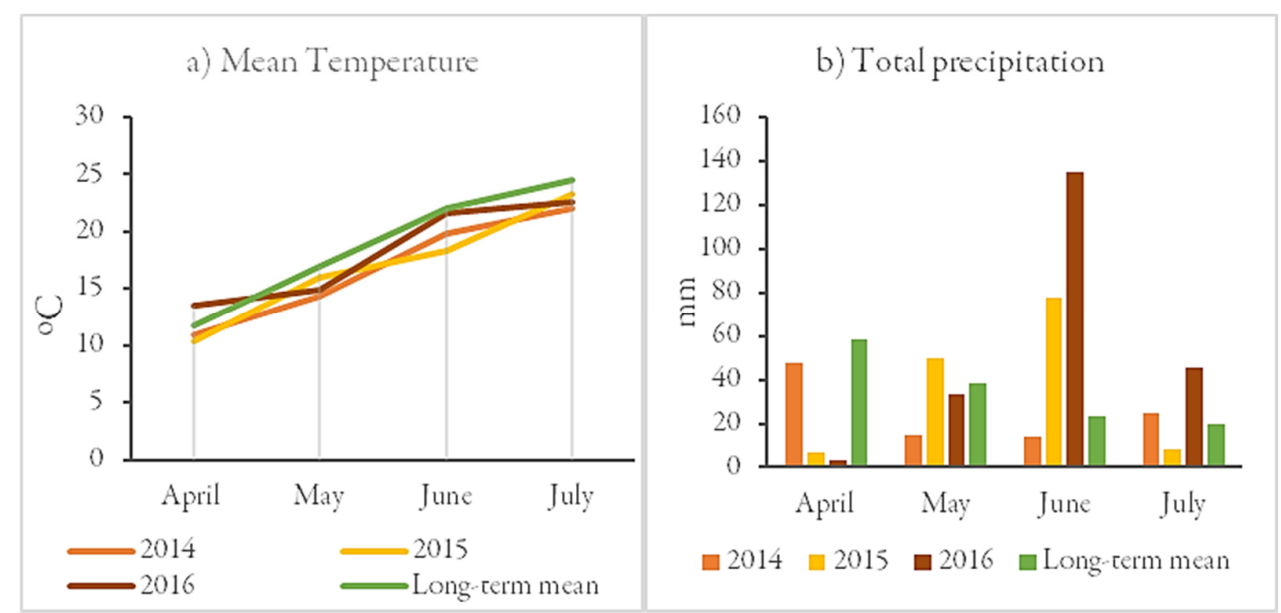

Figure 1. Monthly mean temperature (a) and total precipitation (b) during the experimental period and long-term averages at Tripoli, central Peloponnese

\section{Experimental design and plot management}

The study was established in a field certified as organic and the experimental design was a split-plot with three replicates, two main plots and three sub-plots. Experimental units consisted of plots $24 \mathrm{~m}^{2}(6 \mathrm{~m}$ long and $4 \mathrm{~m}$ wide), spaced 30-cm apart and were managed according to organic agricultural guidelines (EC834/2007). 
The main plot was characterized by two different tillage systems: conventional tillage and minimum tillage. The conventional tillage treatment included moldboard plowing at $25 \mathrm{~cm}$ depth followed by one rotary hoeing and minimum tillage treatment included chiseling at 10-15 cm depth followed by one rotary hoeing in order to prepare a proper seedbed, according to the environmental annual conditions. Within each tillage treatment, the following compost amendments were applied: vermicompost and compost, compared with an unamended control. The two composts differing in their composting process (organic waste converted into compost under aerobic conditions i. by microorganisms: composting, ii. through the interaction of earthworms and microorganisms at room temperature: vermicomposting) and composition (Table 2). The compost treatments were applied manually at rates of 2 tons ha ${ }^{-1}$ and immediately incorporated with rotary hoeing, before the sowing. Camelina was sown between early April to early May (03/04/14, 10/05/15, 13/04/16), at a rate of 6 $\mathrm{kg} \mathrm{ha}^{-1}$, while harvesting took place on early to late July (09/07/14, 31/07/15, 10/07/16). Supplemental irrigation was set up by means of a dripline irrigation system (the water quantity was $50 \mathrm{~mm}$ in $2014,30 \mathrm{~mm}$ in 2015 and $30 \mathrm{~mm}$ in 2016).

Table 2. Main characteristics of the organic amendments: Vermicompost (VC); Compost (CM)

\begin{tabular}{|c|c|c|c|}
\hline & Unit & VC & CM \\
\hline $\mathrm{pH}$ & & 7.2 & 6.6 \\
\hline Total organic substance & $\%$ & 52 & 33 \\
\hline $\mathrm{N}$ & $\mathrm{g} \mathrm{kg}^{-1}$ & 20 & 70 \\
\hline $\mathrm{P}$ & $\mathrm{mg} \mathrm{kg}^{-1}$ & 6500 & 17400 \\
\hline $\mathrm{K}$ & $\mathrm{mg} \mathrm{kg}^{-1}$ & 12450 & 58100 \\
\hline $\mathrm{Mg}$ & $\mathrm{mg} \mathrm{kg}^{-1}$ & 6030 & 12060 \\
\hline
\end{tabular}

\section{Data collection and evaluations}

For the computation of plant height ten randomly selected plants in each plot were measured after flowering and prior to swathing maturity. At full maturity, plants from a $1 \mathrm{~m}^{2}$ area within each plot, were harvested and used to estimate harvest index (HI). The HI was calculated as seed dry weight divided by the dry weight of total above ground biomass. After harvesting the $1 \mathrm{~m}^{2}$, grain harvest separately for each plot using a plot combine. Then the seeds were cleaned and weighed to determine seed yield. 1000-seed weight (TSW) was recorded by taking three representative samples, each of 100 seeds, from each experimental unit, then weighing on the electrical balance and converted to TSW in grams. Both, seed yield and TSW were reported based on $7 \%(\mathrm{w} / \mathrm{w})$ moisture content.

\section{Camelina seed and fatty acid analysis}

Representative seed samples of experimental plot were analyzed for dry matter (DM; Official Method 7.007), crude protein (CP; Official Method 7.016) and so rather than ether extract (EE; Official Method 7.060) according to AOAC (1984). Seed oil and crude protein (CP) content are reported on a dry weight basis as a percentage of whole seed. To obtain the Camelina sativa oil, from a representative seed sample of each experimental unit, a mechanical screw press (TäbyPress Type 20, Sweden) was used. Subsequently, Camelina oil were analyzed for fatty acids (FA) profile according to the method of O' Fallon et al. (2007). For the determination of FA profile, an Agilent $6890 \mathrm{~N}$ gas chromatograph equipped with an HP-88 capillary column $(60 \mathrm{~m} \times 0.25 \mathrm{~mm}$ i.d. with $0.20 \mu \mathrm{m}$ film thickness, Agilent, Santa Clara, USA) and a flame ionization detector (FID) was used. The FID temperature was set at $260{ }^{\circ} \mathrm{C}$ and the chromatographic analysis involved a temperature programmed run starting at $120^{\circ} \mathrm{C}$ held for $1 \mathrm{~min}$. Then followed by 2 step- ramp, one of 1.25 ${ }^{\circ} \mathrm{C} / \mathrm{min}$ to $230^{\circ} \mathrm{C}$, and another of $10^{\circ} \mathrm{C} / \mathrm{min}$ to $240^{\circ} \mathrm{C}$, and each held for $3 \mathrm{~min}$. The flame gases were hydrogen (purity at least $>99 \%$ ) and synthetic air. Helium was used as the carrier gas with a linear velocity set at $30 \mathrm{~cm} / \mathrm{s}$. Each peak was identified and quantified using a 37 component FA methyl esters (FAME) mix standard (Supelco, Sigma-Aldrich, St. Louis, MO, USA). Extra FA standards were used for the cis-9, trans-11, C18:2, trans-10, cis-12 C18:2 and trans-11 C18:1 FA (Sigma-Aldrich, St. Louis, MO, USA). 


\section{Statistical analysis}

Data were subjected to statistical analysis using STATISTICA 7.0 logistic package, considering the years and replications as random, while fertilization and tillage treatments as fixed factors. The experimental data were subjected to multi analysis of variance (MANOVA) and differences between means were determined according to Tukey's test. Correlation analyses were used to describe the relationships between seed quality and yield parameters. The significance level of the Pearson's correlation coefficient $(r)$ was tested for $\mathrm{P}<0.05$.

\section{Results and Discussion}

\section{Climatic conditions and camelina development}

The average air temperatures during the process of this 3-year study were generally in accordance with the multiyear average Figure 1. The only exception was observed in April 2016, which air temperature was slightly greater than the long-term mean. Annual crop-year (April -July) precipitation varied substantially from year to year but averaged $153 \mathrm{~mm}$ which slightly exceeded the long-term average annual precipitation of $140 \mathrm{~mm}$ at the site. The distribution of precipitation has the greatest fluctuations between the experimental years during the months of April and June compare to the monthly long-term mean. High precipitation at the end of June in 2016 and near to harvest time, occurred by a heavy storm which caused approximately a $50 \%$ yield loss without affecting the seed quality traits. Low precipitation in April 2015 and 2016 resulted in delayed seeding in both years because of the too dry soil conditions. Due to delayed sowing, the number of days to harvest decreased for spring camelina as growing season temperatures increased but the number of accumulated GDD differed only slightly among sowing dates (Table 3). These results come in agreement with Gesch (2014) who reported that harvest time seems to be dependent on the accumulation of thermal time and these findings will be useful for camelina producers in order to predict harvest date depending on sowing time.

Spring camelina plants, at the specific agroclimatic conditions, required on average 89 days and $1130{ }^{\circ} \mathrm{C}$ $\mathrm{d}$ thermal time from seeding to harvest. The range of cumulated GDD are reported in Table 3. Similar results were reported in USA (Gesch, 2014) while average values of GDD in Europe and Canada reached $1205^{\circ} \mathrm{C} \mathrm{d}$ and $1276^{\circ} \mathrm{C}$ d respectively, with a range from 993 to $1520 \mathrm{GDD}$ (Zanetti et al., 2017; Krzyżaniak et al., 2019).

Table 3. Dates of sowing and harvest, cumulative growing degree days (GDD) and mean maximum and minimum temperatures of growing season from seeding to harvest, during three consecutive experimental growing seasons (2014-2016)

\begin{tabular}{|c|c|c|c|c|c|}
\hline Year & Sowing date & Harvest date & $\begin{array}{c}\text { Mean Tmax } \\
\left({ }^{\circ} \mathrm{C}\right)\end{array}$ & $\begin{array}{c}\text { Mean T min } \\
\left({ }^{\circ} \mathrm{C}\right)\end{array}$ & $\begin{array}{c}\text { GDD } \\
\left({ }^{\circ} \mathrm{C} \mathrm{d}\right)\end{array}$ \\
\hline 2014 & $03 / 04$ & $09 / 07$ & 25.5 & 8.8 & 1097 \\
\hline 2015 & $10 / 05$ & $31 / 07$ & 27.3 & 11.1 & 1124 \\
\hline 2016 & $13 / 04$ & $10 / 07$ & 27.6 & 9.6 & 1170 \\
\hline
\end{tabular}

\section{Organic camelina performance}

The main effects and interactions among fixed factors on camelina's productive performance are shown in Table 4. In particular, the effects of tillage and compost treatments were highly significant on all measured parameters except for oil content. Furthermore, there were no significant interactive effects among the experimental factors and each factor affected independently camelina's productive and quality features. Beside treatments effects, climatic conditions strongly affected camelina's productivity and seed quality (Table 4). Mean values of the investigated seed and yield quality parameters were higher during the first year compare to the second and third year (Table 5). These observed variations could partially be explained by higher air temperatures in 2015 and 2016 in relative to 2014. Warmer growing season temperatures, especially during seed development, have been reported to decrease seed yield and oil content in oilseed crops (Canvin, 1965; Yaniv et al., 1995). 
Table 4. Combined ANOVA table of the effects of tillage and composts treatments on camelina productive and quality performance

\begin{tabular}{|c|c|c|c|c|c|c|c|c|c|c|c|c|c|c|}
\hline $\begin{array}{l}\text { Source of } \\
\text { variation }\end{array}$ & $\mathrm{PH}$ & TSW & $S \Upsilon$ & $\mathrm{HI}$ & $\mathrm{CP}$ & $\mathrm{OC}$ & OY & $\mathrm{C} 16: 0$ & C18:0 & $\mathrm{C} 18: 1$ & C20:1 & C22:1 & $\begin{array}{c}\text { C18:2n- } \\
6\end{array}$ & $\begin{array}{c}\text { C18:3n- } \\
3\end{array}$ \\
\hline Year $(\mathrm{Y})$ & ** & ** & ** & * & ** & $* *$ & $* *$ & $* *$ & ** & $* *$ & ** & $* *$ & $* *$ & ** \\
\hline Tillage $(\mathrm{T})$ & $\mathrm{ns}$ & * & ns & ns & *** & ns & $\mathrm{ns}$ & $\mathrm{ns}$ & $\mathrm{ns}$ & ns & *** & $\mathrm{ns}$ & $\mathrm{ns}$ & $\mathrm{ns}$ \\
\hline Composts (Cs) & ** & ns & ${ }^{* *}$ & ** & $\mathrm{ns}$ & ns & ** & ** & ns & ** & ** & ** & ** & ** \\
\hline $\mathrm{T} \times \mathrm{Cs}$ & $\mathrm{ns}$ & $\mathrm{ns}$ & ns & ns & $\mathrm{ns}$ & ns & $\mathrm{ns}$ & $\mathrm{ns}$ & ns & $\mathrm{ns}$ & $\mathrm{ns}$ & $\mathrm{ns}$ & $\mathrm{ns}$ & $\mathrm{ns}$ \\
\hline $\mathrm{YxT}$ & $\mathrm{ns}$ & $\mathrm{ns}$ & ns & ns & $\mathrm{ns}$ & ns & $\mathrm{ns}$ & ns & ns & $\mathrm{ns}$ & ns & ns & * & $\mathrm{ns}$ \\
\hline $\mathrm{YxCs}$ & * & $\mathrm{ns}$ & $\mathrm{ns}$ & ns & $\mathrm{ns}$ & ns & * & $* *$ & $\mathrm{~ns}$ & $* *$ & ** & $* *$ & ** & ** \\
\hline $\mathrm{Yx} T \times \mathrm{Cs}$ & ns & $\mathrm{ns}$ & ns & ns & ns & ns & $\mathrm{ns}$ & $\mathrm{ns}$ & ns & $\mathrm{ns}$ & ns & ns & $\mathrm{ns}$ & $\mathrm{ns}$ \\
\hline
\end{tabular}

Plant height (PH), Thousand seed weight (TSW), Seed yield (SY), harvest index (HI), Crude protein content(CP), Oil content (OC), Oil yield (OY), palmitic (C16:0), stearic (C18:0), oleic (C18:1), gondoic (C20:1), erucic (C22:1), linoleic (C18:2n-6), a-linolenic(C18:3n-3).

non-significant (ns); ${ }^{*}$ and ${ }^{* *}$, significant at $5 \%$, and $1 \%$ probability levels, respectively.

\section{Effect tillage system on yield and seed qualitative traits}

No conclusive data is currently available on camelina's yield and quality with respect to tillage practices. The results of this study indicated that different tillage treatments influenced significantly the TSW $(\mathrm{P}<0.05)$, gondoic acid $(\mathrm{P}<0.01)$ and the $\mathrm{CP}$ content $(\mathrm{P}<0.01)$, while the plant height, $\mathrm{HI}$, seed yield, oil content and oil yield were not affected (Table 4). In conventional tillage system camelina reached on average the highest $\mathrm{CP}$ content and TSW compared to minimum tillage (Table 5). Many studies (Laudicina et al., 2010; Fernandez et al., 2019) in different agroclimatic conditions confirmed that intensive tillage led to a higher soil moisture, aeration, organic substrates accessibility and $\mathrm{NO}_{3}-\mathrm{N}$ content than reduced tillage. Moreover, nitrogen availability might increase the absorbed nitrogen by plant root which raise protein metabolism and subsequently the CP content in seeds (El-Nakhlawy and Bakhashwain, 2009). Beside the increase in CP content the oil content did not differ, potentially at the expense of other seed components. On spring camelina, Afshar et al. (2016) found that tillage system did not affect oil and protein content whereas seed yield increased significantly in conventional tillage compared to no-till. Concerning the FA profile, tillage system did not exert a significant effect on the proportion of FAs apart from gondoic acid $(\mathrm{P}<0.01)$, the concentration of which was greater in minimum tillage system (Table 7). Gesch and Cermak (2011) also reported on fall-seeded camelina that tillage system had not a significant effect on FA content, besides of gondoic acid, while seed yield and oil content did not differ constantly among the surveyed tillage systems in that study.

The findings of this research indicated that minimum tillage for camelina can give comparable seed and oil yields to conventional tillage, and should result in reducing the intensity of the soil tillage in the specific Mediterranean conditions. Minimum tillage treatment can be suitable for high density crops (Kisic et al., 2010) and parallel can give greater soil strength and quality in order to solve soil erosion problems, mitigate the climate harms and reduce energy consumption (Holland, 2004). However, there has been a discordance in the research on the responses of various oilseed crops to tillage system with lower yields have been reported under conventional tillage compare to minimum (Bilalis et al., 2010; Abdullah, 2014; Seddaiu et al., 2016) as well as higher yields under conventional tillage (Kasap and Coskun, 2006; Torabi et al., 2008) and little effect of tillage treatment on yield (Hocking et al., 2003). Taking in account this variance it could be concluded that the interaction between the tillage method and the environment is more important that the tillage method alone (Rasmussen, 1999; Roper et al., 2013). 
Table 5. The effect of year, tillage system and composts application on camelina yield and seed quality characteristics

\begin{tabular}{|c|c|c|c|c|c|c|c|}
\hline Parameter & $\begin{array}{c}\text { Plant height } \\
(\mathrm{cm})\end{array}$ & TSW(g) & $\begin{array}{c}\text { Seed yield } \\
\left(\mathrm{kg} \mathrm{ha}^{-1}\right)\end{array}$ & HI & $\begin{array}{c}\text { CP content } \\
(\% \mathrm{DM})\end{array}$ & $\begin{array}{c}\text { Oil content } \\
(\% \mathrm{DM})\end{array}$ & $\begin{array}{c}\text { Oil yield } \\
\left(\mathrm{kg} \mathrm{ha}^{-1}\right)\end{array}$ \\
\hline \multicolumn{7}{|c|}{ Year } \\
\hline 2014 & $76.57 \mathrm{a}$ & $0.96 \mathrm{a}$ & $912.77 \mathrm{a}$ & $0.24 \mathrm{a}$ & $26.13 \mathrm{a}$ & $41.54 \mathrm{a}$ & $378.48 \mathrm{a}$ \\
\hline 2015 & $71.22 \mathrm{~b}$ & $0.91 \mathrm{~b}$ & $781.90 \mathrm{~b}$ & $0.28 \mathrm{~b}$ & $28.75 \mathrm{~b}$ & $37.82 \mathrm{~b}$ & $295.01 \mathrm{~b}$ \\
\hline 2016 & $65.13 \mathrm{c}$ & $0.87 \mathrm{~b}$ & $673.26 \mathrm{~b}$ & $0.30 \mathrm{~b}$ & $27.47 \mathrm{c}$ & $39.05 \mathrm{c}$ & $262.31 \mathrm{~b}$ \\
\hline \multicolumn{7}{|c|}{ Tillage system, average of years } & \\
\hline CT & 70.20 & $0.93 \mathrm{a}$ & 770.57 & 0.28 & $27.87 \mathrm{a}$ & 39.28 & 303.24 \\
\hline MT & 71.77 & $0.89 \mathrm{~b}$ & 808.05 & 0.27 & $26.98 \mathrm{~b}$ & 39.66 & 320.62 \\
\hline Composts treatments $\left(\mathrm{kg} \mathrm{ha}^{-1}\right)$ average of years & \\
\hline Control & $65.60 \mathrm{a}$ & 0.91 & $554.04 \mathrm{a}$ & $0.25 \mathrm{a}$ & 27.32 & 39.75 & $220.41 \mathrm{a}$ \\
\hline VC & $70.10 \mathrm{~b}$ & 0.90 & $681.80 \mathrm{~b}$ & $0.27 \mathrm{ab}$ & 27.55 & 39.49 & $269.40 \mathrm{~b}$ \\
\hline CM & $77.24 \mathrm{c}$ & 0.92 & $1132.10 \mathrm{c}$ & $0.30 \mathrm{~b}$ & 27.67 & 39.16 & $445.98 \mathrm{c}$ \\
\hline
\end{tabular}

Mean values in each column followed by a different letter are significantly different according to Tukey's test ( $\mathrm{p}$ 0.05). CT: conventional tillage, MT: minimum tillage, VC: vermicompost, CM: compost, harvest index (HI).

\section{Effect of compost treatments on yield and seed qualitative traits}

Compost application influenced highly $(\mathrm{P}<0.01)$ camelina's productivity and seed chemical composition (Table 4). Regardless of the tillage system, the type of compost treatment had a significant influence on plant height, HI, seed yield and oil yield, but did not influence oil and CP content (Table 5).

The maximum height of camelina plants obtained on soil amended with compost $(77.24 \mathrm{~cm})$ compare with plants grown on soil amended with vermicompost $(70.10 \mathrm{~cm})$ or unamended soil $(65.60 \mathrm{~cm})$. Plant height is an important plant characteristic which is correlated highly significant to seed yield $(r=0.75, \mathrm{P}<0.01)$ and oil yield $(\mathrm{r}=0.77, \mathrm{P}<0.01)$ and is mostly influenced by agroclimatic conditions, as reported by Katar et al. (2012). These findings are in agreement with the present study, in which the effects of organic amendments on plant height were associated with agroclimatic conditions during the experimental years (Table 4). In the third year of the experiment when average daily temperature exceeded the long-term average during April, significant differences were obtained between compost $(74.44 \mathrm{~cm})$, vermicompost $(63.92 \mathrm{~cm})$ applications and the unamended control $(57.05 \mathrm{~cm})$. While, in the first and second year of the experiment plant height peaked in response mainly to compost application with the highest value being observed in the first year $(82.39 \mathrm{~cm})$.

The yield potential of organically grown camelina reported in the present study was evaluated to 1132.10 $\mathrm{kg} \mathrm{ha}^{-1}$ (Table 5), which is equal to what is found in conventionally grown camelina in other locations of Greece (Zanetti et al., 2017) and in Mediterranean environments around the world (Campbell et al., 2013; Schillinger, 2019). Addition of compost and vermicompost showed, on average, $104 \%$ and $23 \%$ greater camelina yield respectively, compared to unamended control. The HI was also increased by compost application compared to control, while HI values obtained with vermicompost applications did not significantly differ from those of the compost and control (Table 5). These increases might be attributed to the: i) type of organic amendment (richer composition of compost compare to vermicompost) that supplied specific camelina's nutrient requirements (Duong et al., 2012; Nkoa et al., 2014) and ii) improved chemical, hydro-physical and biological properties of treated soils (Adugna, 2018). Consequently, oil yield was also significantly higher in compost and vermicompost amended soil than in unamended (Table 5), a result that was expected due to the high positive correlation with seed yield (Table 6), as both traits are closely related. Furthermore, oil yield was significantly $(\mathrm{P}<0.05)$ affected by interaction among year and the type of organic amendment (Table 4). In years characterized by high air temperatures (2015 and 2016), oil yields induced a significant decrease relating to compost amendment ( $401.90 \mathrm{~kg} \mathrm{ha}^{-1}$ and $368.84 \mathrm{~kg} \mathrm{ha}^{-1}$, respectively) in comparison with the first year of the experiment $\left(567.21 \mathrm{~kg} \mathrm{ha}^{-1}\right)$. 
Similar results of organic amendments on plant growth and productivity were obtained by other researchers (Sharma, 2017; Joshi et al., 2017). However, there is a considerable variability of results in the literature due to various experimental techniques, climate, soil type and organic material characteristics.

Notwithstanding that compost's application did not influence significantly the oil content, it caused some alteration on the content of saturated and unsaturated acids in relation to growing season (Table 4, Table 7). Other studies in oilseeds crops and camelina have also shown that FA profile did not consistently differ among experimental years between the same fertilization treatments (Urbaniak et al., 2008; Gao et al., 2010; Aytac et al., 2017). The interaction of year and organic amendment was significant on a-linolenic, linoleic, oleic, palmitic, erucic and gondoic acids content (Table 7). The application of vermicompost tended to be less effective than compost as regards the improving of a-linolenic acid content, which is essential for camelina's oil nutritional quality, while both organic amendments tend to increase the content of palmitic and linoleic acids. Kirkhus et al. (2013) also referred that organic fertilization influenced camelina's oil profile although seasonal variations were larger than variations observed by fertilization.

Table 6. Correlation coefficients between yield and quality traits of camelina

\begin{tabular}{|c|c|c|c|c|c|c|c|c|}
\hline Variable & $\begin{array}{c}\text { Plant } \\
\text { height }\end{array}$ & TSW & Seed yield & $\begin{array}{c}\text { CP } \\
\text { content }\end{array}$ & Oil content & Oil yield & C18:2n-6 & C18:3n-3 \\
\hline $\begin{array}{c}\text { Plant } \\
\text { height }\end{array}$ & 1 & & & & & & & \\
\hline TSW & $0.37^{*}$ & 1 & & & & & & \\
\hline Seed yield & $0.75^{* *}$ & $0.32^{*}$ & 1 & & & & & \\
\hline CP content & $0.22^{\text {ns }}$ & $0.36^{*}$ & $0.16^{\mathrm{ns}}$ & 1 & & & & \\
\hline Oil content & $0.24^{\mathrm{ns}}$ & $-0.47^{* *}$ & $-0.23^{\mathrm{ns}}$ & $-0.82^{* *}$ & 1 & & & \\
\hline Oil yield & $0.77^{* *}$ & $0.36^{*}$ & $0.90^{* *}$ & $-0.19^{\mathrm{ns}}$ & $0.28^{\mathrm{ns}}$ & 1 & & \\
\hline C18:2n-6 & $0.26^{\mathrm{ns}}$ & $-0.39^{*}$ & $-0.28^{\mathrm{ns}}$ & $0.54^{* *}$ & $-0.75^{* *}$ & $-0.25^{\mathrm{ns}}$ & 1 & \\
\hline C18:3n-3 & $-0.24^{\mathrm{ns}}$ & $0.30^{\mathrm{ns}}$ & $0.18^{\mathrm{ns}}$ & $-0.58^{* *}$ & $0.69^{* *}$ & $0.32^{\mathrm{ns}}$ & $-0.88^{* *}$ & 1 \\
\hline
\end{tabular}

ns: non-significant, ${ }^{*},{ }^{* *}$ and ${ }^{* * *}$, significant at $5 \%, 1 \%$ and $0.1 \%$ probability levels, respectively

\section{Seed chemical composition}

In the present study the oil content ranged from 39 to $41.5 \%$ and CP content ranged from 26 to $27 \%$ which were greater or equivalent to values reported by other researches on conventionally grown camelina in similar climatic conditions (Angelini et al., 1997; Zanetti et al., 2017). Both oil and CP contents were not affected by the significant increasing of seed yield among composts application (Table 5 ). These findings may present a useful resource for improving seed yields without an impact on the quantity of produced oil. The negative influence of inorganic fertilization on oil content was underlined by many authors also in camelina who reported that the increase of nitrogen rate resulted in higher seed yield and CP content but lower oil content in the seeds (Jiang et al., 2013; Jiang et al., 2014; Sintim et al., 2015). Studies on canola that compared inorganic and organic fertilization confirmed the need for prudent use of nitrogen fertilization to minimize the potential reductions on oil content and quality and support the organic applications as an alternative to negative effects of synthetic fertilizers (Gao et al., 2010; Ali et al., 2011). Whereas, a promising alternative in sustainable and productive farming in oilseed crops such as camelina, which may mitigate the disparity of yield and quality, could be the combination of organic and inorganic fertilization (Mohammadi and Rokhazdi, 2012; Joshi et al., 2017).

Concerning the FA composition presented in this study (Table 7), the range of FA profile are consistent to previous studies (Vollmann and Eynck, 2015; Righini et al., 2019). Notwithstanding, a-linolenic (27.9428.51\%) and linoleic (21.63-22.42\%) acids remained the most abundant FAs featuring the uniqueness of camelina oil. Pearson correlation analysis revealed highly significant correlations between the levels of linoleic and linolenic acids and between these FAs and oil content (Table 6) which is consistent with the research performed by Obour et al. (2017). Growing organic camelina in the specific agroclimatic conditions increased 
mainly saturated fatty acids (SFAs) and monounsaturated fatty acids (MUFAs) at the expense of polyunsaturated fatty acids (PUFAs), which constitute $52.9 \%$ of the total FAs in camelina oil and is in line with Zanetti et al. (2017). A high number of days with maximal temperature above $25^{\circ} \mathrm{C}$ during grain development has referred to reduce a-linolenic acid content and PUFAs and increase MUFAs due to their negative correlation (Leclère et al., 2021). Several days, in the present study, during seed feeling had maximum temperatures above $25^{\circ} \mathrm{C}$, which could explain the reduction of a-linolenic acid proportion and PUFAs. These results come also in agreement with Rodríguez-Rodríguez et al. (2013) who mentioned that warmer climates favor lower levels of PUFAs than cooler climates. This profile may be more desirable for biodiesel production since higher contents of SFAs and MUFAs can influence in positive way the quality of biodiesel compare to PUFAs (Pinzi et al., 2009).

Table 7. The effect of year, tillage system and compost application on fatty acid profile of camelina. Main and total polyunsaturated (PUFA), monounsaturated (MUFA), and saturated fatty (SFA) acids in camelina seed as a percentage of aggregate oil

\begin{tabular}{|c|c|c|c|c|c|c|c|}
\hline \multirow{2}{*}{ Parameter } & \multicolumn{2}{c|}{ SFA (\%) } & \multicolumn{3}{c|}{ PUFA (\%) } \\
\cline { 2 - 7 } & C16:0 & C18:0 & C18:1 & C20:1 & C22:1 & C18:2n-6 & C18:3n-3 \\
\hline \multicolumn{7}{|c|}{ Year } \\
\hline 2014 & $6.04 \mathrm{a}$ & $2.58 \mathrm{a}$ & $18.78 \mathrm{a}$ & $13.28 \mathrm{a}$ & $2.57 \mathrm{a}$ & $21.63 \mathrm{a}$ & $28.51 \mathrm{a}$ \\
\hline 2015 & $6.22 \mathrm{~b}$ & $2.55 \mathrm{~b}$ & $18.25 \mathrm{~b}$ & $13.39 \mathrm{~b}$ & $2.79 \mathrm{~b}$ & $22.42 \mathrm{~b}$ & $27.94 \mathrm{c}$ \\
\hline 2016 & $6.29 \mathrm{~b}$ & $2.54 \mathrm{~b}$ & $17.56 \mathrm{c}$ & $13.35 \mathrm{~b}$ & $2.84 \mathrm{c}$ & $22.07 \mathrm{c}$ & $28.25 \mathrm{~b}$ \\
\hline \multicolumn{8}{|c|}{ Tillage system, average of years } \\
\hline CT & 6.19 & 2.55 & 18.20 & $13.39 \mathrm{a}$ & 2.74 & 22.10 & 28.23 \\
\hline MT & 6.16 & 2.57 & 18.19 & $13.45 \mathrm{~b}$ & 2.71 & 22.02 & 28.27 \\
\hline \multicolumn{7}{|c|}{ Composts treatments (kg ha-1), average of years } \\
\hline Control & $6.11 \mathrm{a}$ & 2.56 & $18.24 \mathrm{a}$ & $13.50 \mathrm{a}$ & $2.76 \mathrm{a}$ & $21.84 \mathrm{a}$ & $28.31 \mathrm{a}$ \\
\hline VC & $6.24 \mathrm{~b}$ & 2.55 & $18.22 \mathrm{a}$ & $13.39 \mathrm{~b}$ & $2.69 \mathrm{~b}$ & $22.11 \mathrm{~b}$ & $28.19 \mathrm{~b}$ \\
\hline CM & $6.21 \mathrm{~b}$ & 2.54 & $18.12 \mathrm{~b}$ & $13.35 \mathrm{~b}$ & $2.75 \mathrm{a}$ & $22.17 \mathrm{~b}$ & $28.37 \mathrm{a}$ \\
\hline
\end{tabular}

Mean values in each column followed by a different letter are significantly different according to Tukey's test $(\mathrm{p}<$ $0.05)$. Fatty acids: palmitic (C16:0), stearic (C18:0), oleic (C18:1), gondoic (C20:1), erucic (C22:1), linoleic (C18:2n6), a- linolenic(C18:3n-3). CT: conventional tillage, MT: minimum tillage, VC: vermicompost, CM: compost.

\section{Conclusions}

The present study demonstrates that spring camelina seems to be well suited under organic production while satisfactory seed yields and desirable quality traits can be obtained. The present results highlighted the importance of the type of the organic amendment on plant growth and yield in contrast to tillage system which did not reveal such a strong effect. Moreover, the effect of organic amendments on fatty acid profile was strongly related with the specific climatic conditions of each growing season, than the effect of the application of organic amendments alone. Compost application combined with minimum tillage was found suitable for achieving optimal seed yields without adverse effects on the quality of produced seeds. Further research is needed to achieve a successful organic camelina cultivation under different agroclimatic conditions.

\section{Authors' Contributions}

Conceptualization: FA and DB; Data curation: FA; Formal analysis: FA; Methodology: DB and ET; Resources: ET, DB and FA; Software: FA and DB; Supervision: DB; Writing-original draft: FA; Writingreview and editing: ET and DB. All authors read and approved the final manuscript. 


\section{Acknowledgements}

This research received no specific grant from any funding agency in the public, commercial, or not-forprofit sectors.

\section{Conflict of Interests}

The authors declare that there are no conflicts of interest related to this article.

\section{References}

Abdullah A (2014). Minimum tillage and residue management increase soil water content, soil organic matter and canola seed yield and seed oil content in the semiarid areas of Northern Iraq. Soil and Tillage Research 144:150-155. https://doi.org/10.1016/j.still.2014.07.017

Adugna G (2018). A review on impact of compost on soil properties, water use and crop productivity. Agricultural Science Research Journal 4:93-104. https://doi.org/10.14662/ARJASR2016.010

Afshar RK, Mohammed YA, Chen C (2016). Enhanced efficiency nitrogen fertilizer effect on camelina production under conventional and conservation tillage practices. Industrial Crops and Products 94:783-789. https://doi.org/10.1016/j.indcrop.2016.09.043

Akk E, Ilumäe E (2005). Possibilities of growing Camelina sativa in ecological cultivation. Estonian Res Institute Agric. In Proceedings of the seminar: environmentally friendly food production system: Requirements for plant breeding and seed production. State Stende Plant Breeding Station, Talsi, Lithuania pp 120-122.

Ali ME, Fathi A, Mohamed OH, El-Edfawy Y (2011). Response of canola productivity and quality to bio-organic and inorganic N-fertilizers. Journal of Soil Sciences and Agricultural Engineering 2(12):1255-1272. https://doi.org/10.21608/jssae.2011.56472

Angelini LG, Moscheni E, Colonna G, Belloni P, Bonari E (1997). Variation in agronomic characteristics and seed oil composition of new oilseed crops in central Italy. Industrial Crops and Products 6:313-323. https://doi.org/10.1016/S0926-6690(97)00022-8

Angelopoulou F, Anastasiou E, Fountas S, Bilalis D (2020). Evaluation of organic camelina crop under different tillage systems and fertilization types using proximal remote sensing. Bulletin UASVM Horticulture 77:1-6. http://dx.doi.org/10.15835/buasvmcn-hort:2019.0025

Association of Official Analytical Chemists International (1984). Official methods of analysis (14th ed). AOAC, Arlington, VA.

Aytac Z, Gulmezoglu N, Saglam T, Kulan EG, Selengil U, Hosgun HL (2017). Changes in N, K, and fatty acid composition of black cumin seeds affected by nitrogen doses under supplemental potassium application. Journal of Chemistry 1-7. https://doi.org/10.1155/2017/3162062

Bates RG (1964). Determination of pH. Theory and Practice. John Wiley and Sons, New York. https://doi.org/10.1002/bbpc.19730770918

Bilalis D, Karkanis A, Papastylianou P, Patsiali S, Athanasopoulou M, Barla G, Kakabouki I (2010). Response of organic linseed (Linum usitatissimum L.) to the combination of tillage systems, (minimum, conventional and no-tillage) and fertilization practices: Seed and oil yield production. Australian Journal of Crop Science 4(9):700-705. https://www.researchgate.net/publication/262178946

Blevins RL, Frye WW (1993). Conservation Tillage: An Ecological Approach to Soil Management. Advances in Agronomy 51:33-78. https:// dx.doi.org/10.1111/j.1439-037X.2011.00488.X

Bouby L (1998). Two early finds of gold-of-pleasure (Camelina sp.) in middle Neolithic and Chalcolithic sites in western France. Antiquity 72:391-398. https://doi.org/10.1017/S0003598X0008666X

Bremmer JM (1965). Total nitrogen. In C. A. Black et al. (Ed) Methods of soil analysis, Part 2. American Society of Agronomy, Madison, USA pp 1149-1178. https://doi.org/10.2134/agronmonogr9.2.c32 
Campbell M, Rossi A, Erskine W (2013). Camelina (Camelina sativa (L.) Crantz): Agronomic potential in Mediterranean environments and diversity for biofuel and food uses. Crop and Pasture Science 64(4):388-98. https://doi.org/10.1071/CP13054

Canvin DT (1965). The effect of temperature on the oil content and fatty acid composition of the oils from several oil seed crops. Canadian Journal of Botany 43(1):63-69. https://doi.org/10.1139/b65-008

Chaturvedi S, Bhattacharya A, Khare SK, Kaushik G (2017). Camelina sativa: An emerging biofuel crop. Handbook of Environmental Materials Management pp 1-38. https://doi.org/10.1007/978-3-319-73645-7_110

Dharavath RN, Singh S, Chaturvedi S, Luqman S (2016). Camelina sativa (L.) Crantz A mercantile crop with speckled pharmacological activities. Annals of Phytomedicine 5:6-2. https://doi.org/10.21276/ap.2016.5.2.2

Diacono M, Montemurro F (2010). Long-term effects of organic amendments on soil fertility. A review. Agronomy for Sustainable Development 30:401-422. https://doi.org/10.1051/agro/2009040

Duong T, Penfold C, Marschner P (2012). Amending soils of different texture with six compost types: Impact on soil nutrient availability, plant growth and nutrient uptake. Plant and Soil 354:197-209. https://doi.org/10.1007/s11104-011-1056-8

El-Nakhlawy FS, Bakhashwain AA (2009). Performance of canola (Brassica napus L.) seed yield, yield components and seed quality under the effects of four genotypes and nitrogen fertilizer rates. Journal of King Abdulaziz University-meteorology, Environment and Arid Land Agriculture Sciences 20:33-47. https://oi.org/ 10.4197/met.20-2.3

Falasca SL, del Fresno MC, Waldman C (2014). Developing an agro-climatic zoning model to determine potential growing areas for Camelina sativa in Argentina. QScience Connect 4:1-11. https://doi.org/10.5339/connect.2014.4

Fernandez M, Zentner R, Schellenberg M, Aladenola O, Leeson J, St. Luce M, ... Cutforth H (2019). Soil Fertility and Quality Response to Reduced Tillage and Diversified Cropping under Organic Management. Agronomy Journal 111(2):781-792. https://doi.org/10.2134/agronj2018.01.0028

Gao J, Thelen KD, Min DH, Smith S, Hao X, Gehl R (2010). Effects of manure and fertilizer applications on canola oil content and fatty acid composition. Agronomy Journal 102(2):790-797. https://doi.org/10.2134/agronj2009.0368

Gesch RW (2014). Influence of genotype and sowing date on camelina growth and yield in the north central U.S. Industrial Crops and Products 54:209-215. https://doi.org/10.1016/j.indcrop.2014.01.034

Gesch RW, Cermak SC (2011). Sowing date and tillage effects on fall-seeded Camelina in the Northern Corn Belt. Agronomy Journal 103(4):980-987. https://doi.org/10.2134/agronj2010.0485

Goss M, Tubeileh A, Goorahoo D (2013). A Review of the use of organic amendments and the risk to human health. Advances in Agronomy 120:275-379. https://doi.org/10.1016/B978-0-12-407686-0.00005-1

Henriksen BIF, Lundon AR, Prestløkken E, Abrahamsen U, Eltun R (2009). Nutrient supply for organic oilseed crops and quality of potential protein feed for ruminants and poultry. Agronomy Research 7:592-598. https://agronomy.emu.ee/tag/turnip-rape/

Hocking PJ, Mead JA, Good AJ, Diffey SM (2003). The response of canola (Brassica napus L.) to tillage and fertilizer placement in contrasting environments in southern New South Wales. Australian Journal of Experimental Agriculture 43(11):1323-1335. https://doi.org/10.1071/EA02233

Holland J (2004). The environmental consequences of adopting conservation tillage in Europe: Reviewing the evidence. Agriculture Ecosystems and Environment 103(1):1-25. https://doi.org/10.1016/j.agee.2003.12.018

Jiang Y, Caldwell CD, Falk KC, Lada RR, MacDonald D (2013). Camelina Yield and Quality Response to Combined Nitrogen and Sulfur. Agronomy Journal 105(6):1847-1852. https://doi.org/10.2134/agronj2013.0240

Jiang Y, Caldwell CD, Falk KC (2014). Camelina seed quality in response to applied nitrogen, genotype and environment. Canadian Journal of Plant Science 94(5):971-980. https://doi.org/10.4141/cjps2013-396

Joshi SK, Ahamada S, Meher LC, Agarwal A, Nasim M (2017). Growth and yield response of Camelina sativa to inorganic fertilizers and farmyard manure in hot semi-arid climate of India. Advances in Plants and Agriculture Research 7:305-309. https://doi.org/10.15406/apar:2017.07.00258

Kasap A, Coskun M (2006). Sunflower Yields and Energy Consumption as Affected by Tillage Systems. Asian Journal of Plant Sciences 5:37-40. https://doi.org/10.3923/ajps.2006.37.40

Katar D, Arslan Y, Subasi I (2012). Genotypic Variations on yield, yield components and oil quality in some camelina (Camelina sativa (L.) Crantz) genotypes. Turkish Journal of Field Crops 17(2):105-110. https://doi.org/10.17557/TJFC.68628 
Keshavarz-Afshar R, Mohammed YA, Chen C (2015). Energy balance and greenhouse gas emissions of dryland camelina as influenced by tillage and nitrogen. Energy 91:105-1063. https://doi.org/10.1016/j.energy.2015.07.136

Keshavarz- Afshar R, Mohammed YA, Chen C (2016). Enhanced efficiency nitrogen fertilizer effect on camelina production under conventional and conservation tillage practices. Industrial Crops and Products 94:783-789. https://doi.org/10.1016/j.indcrop.2016.09.043

Khan MA, Sharma V, Shukla RK (2016). Response of sunflower (Helianthus annuus L.) to organic manure and biofertilizer under different levels of mycorrhiza and sulphur in comparison with inorganic fertilizer. Journal of Crop and Weed 12(1):81-86. http://cwssbckv.org/Journal/default.aspx

Kirkhus B, Russenes A, Haugen JE, Vogt G, Borge GI, Henriksen BI (2013). Effects of environmental factors on edible oil quality of organically grown Camelina sativa. Journal of Agricultural and Food Chemistry 61(13):3179-3185. https://doi.org/10.1021/jf304532u

Kisic I, Basic F, Birkas M, Jurisic A, Bicanic V (2010). Crop yield and plant density under different tillage systems. Agriculturae Conspectus Scientificus 75:1-7. https://hrcak.srce.hr/53002

Krzyżaniak M, Stolarski MJ, Tworkowski J, Puttick D, Eynck, C, Załuski D, Kwiatkowski J (2019). Yield and seed composition of 10 spring camelina genotypes cultivated in the temperate climate of Central Europe. Industrial Crops and Products 138:111443. https://doi.org/10.1016/j.indcrop.2019.06.006

Laudicina VA, Badalucco L, Palazzolo E (2010). Effects of compost input and tillage intensity on soil microbial biomass and activity under Mediterranean conditions. Biology and Fertility of Soils 47(1):63-70. https://doi.org/10.1007/s00374-010-0502-8

Leclère M, Lorent AR, Jeuffroy MH, Butier A, Chatain C, Loyce C (2021). Diagnosis of camelina seed yield and quality across an on-farm experimental network. European Journal of Agronomy 122:126190. https://doi.org/10.1016/j.eja.2020.126190

Mohammadi K, Rokhzadi A (2012). An integrated fertilization system of canola (Brassica napus L.) production under different crop rotations. Industrial Crops and Products 37(1):264-269. https://doi.org/10.1016/j.indcrop.2011.12.023

Moser B (2010). Camelina (Camelina sativa L.) oil as a biofuel's feedstock: Golden opportunity or false hope? Lipid Technology 22(12):270-273. https://doi.org/10.1002/lite.201000068

Nkoa R, Ondoua B, Voroney P, Tambong J (2014). Evidence of the interaction between crop species and organic amendments: modelling of the differential grain yield response of wheat, soybean, and canola to organic amendments. Sustainable Agriculture Research 3(4):33-45. https://doi.org/10.5539/sar.v3n4p33

Obour AK, Sintim YH, Obeng E, Jeliazkov DV (2015). Oilseed Camelina (Camelina sativa L Crantz): Production Systems, Prospects and Challenges in the USA Great Plains. Advantages in Plants and Agriculture Research 2(2):00043. https://doi.org/10.15406/apar:2015.02.00043

Obour AK, Obeng E, Mohammed YA, Ciampitti IA, Durrett TP, Aznar-Moreno JA, Chen C (2017). Camelina seed yield and fatty acids as influenced by genotype and environment. Agronomy Journal 109(3):1-10. https://doi.org/10.2134/agronj2016.05.0256

O'Fallon JV, Busboom JR, Nelson ML, Gaskins CT (2007). A direct method for fatty acid methyl ester synthesis: application to wet meat tissues, oils, and feedstuffs. Journal of Animal Science 85(6):1511-1521. https://doi.org/10.2527/jas.2006-491

Ogbonna P, Umar-Shaaba YG (2011). Yield responses of sesame (Sesamium indicum L) to rates of poultry manure application and time of planting in a derived savannah ecology of south eastern Nigeria. African Journal of Biotechnology 10:14881-14887. https://doi.org/10.5897/AJB11.1989

Pasricha NS, Aulakh MS, Bahl GS, Baddesha HS (1988). Fertilizer use research in oilseed crops. Fertilizer News 33:1522. https://www.researchgate.net/publication/285503774_Fertilizer_use_research_in_oilseed_crops

Pinzi S, Garcia IL, Lopez-Gimenez FJ, Luque de Castro MD, Dorado G, Dorado MP (2009). The ideal vegetable oil-based biodiesel composition: A review of social, economical and technical implications. Energy Fuels 23:2325-2341. https://doi.org/10.1021/ef801098a

Putnam DH, Budin JT, Field LA, Breene WM (1993). Camelina: A promising low-input oilseed. In: Janick J and Simon JE (Eds.). New crops. Wiley, New York, pp 314-322.

Rasmussen KJ (1999). Impact of plough less soil tillage on yield and soil quality: A Scandinavian review. Soil and Tillage Research 53:3-14. https://doi.org/10.1016/S0167-1987(99)00072-0 
Righini D, Zanetti F, Martínez-Force E, Mandrioli M, Toschi TG, Monti A (2019). Shifting sowing of camelina from spring to autumn enhances the oil quality for bio-based applications in response to temperature and seed carbon stock. Industrial Crops and Products 137:66-73. http://dx.doi.org/10.1016/j.indcrop.2019.05.009

Rodríguez-Rodríguez MF, Sánchez-García A, Salas JJ, Garcés R, Martínez-Force E (2013). Characterization of the morphological changes and fatty acid profile of developing Camelina sativa seeds. Industrial Crops and Products 50:673-679. https://doi.org/10.1016/j.indcrop.2013.07.042

Roper M, Ward P, Keulen A, Hill J (2013). Under no-tillage and stubble retention, soil water content and crop growth are poorly related to soil water repellency. Soil and Tillage Research 126:143-150. https://doi.org/10.1016/j.still.2012.09.006

Schillinger W (2019). Camelina: Long-term cropping systems research in a dry Mediterranean climate. Field Crops Research 235:87-94.

Seddaiu G, Iocola I, Farina R, Orsini R, Iezzi G, Roggero PP (2016). Long term effects of tillage practices and N fertilization in rainfed Mediterranean cropping systems: Durum wheat, sunflower and maize grain yield. European Journal of Agronomy 77:166-178. https://doi.org/10.1016/j.eja.2016.02.008

Sharma RK, Sharma SK, Balyan JK (2017). Productivity and profitability of Indian mustard under different organic nutrient management practices in semi-arid region. Journal of Oilseed Brassica 8:89-94. http://srmr.org.in/ojs/index.php/job/article/view/169/140

Sintim HY, Zheljazkov VD, Obour AK, Garcia y Garcia A, Foulke TK (2015). Influence of nitrogen and sulfur application on camelina performance under dryland conditions. Industrial Crops and Products 70:253-259. https://doi.org/10.1016/j.indcrop.2015.03.062

Sintim H, Zheljazkov V, Obour A, Garcia y Garcia A, Foulke T (2016). Evaluating agronomic responses of camelina to seeding date under rain-fed conditions. Agronomy Journal 108(1): 349-357. https://doi.org/10.2134/agronj2015.0153

Thomas GW (1982). Exchangeable cations. In: Page, A.L. (Ed), Methods of Soil Analysis: Part 2, Chemical and Microbiological Properties. American Society of Agronomy and Soil Science Society of America, Madison pp 159-165.

Torabi H, Naghdibadib HA, Omidi H, Amirshekaria H, Mohammad M (2008). Effects of soil tillage, canola (Brassica napus L.) cultivars and planting date on canola yield, and oil and some biological and physical properties of soil. Archives of Agronomy and Soil Science 54:175-188. https://doi.org/10.1080/03650340701814292

Urbaniak SD, Caldwell CD, Zheljazkov VD, Lada R, Luan L (2008). The effect of cultivar and applied nitrogen on the performance of Camelina sativa L. in the Maritime Provinces of Canada. Canadian journal of plant science 88(1):111-119. https://doi.org/10.4141/CJPS07115

Vollmann J, Moritz T, Kargl C, Baumgartner S, Wagentrist H (2007). Agronomic evaluation of camelina genotypes selected for seed quality characteristics. Industrial Crops and Products 26(3):270-277. https://doi.org/10.1016/j.indcrop.2007.03.017

Vollmann J, Eynck C (2015). Camelina as a sustainable oilseed crop: Contributions of plant breeding and genetic engineering. Biotechnology Journal 10(4):525-535. https://doi.org/10.1002/biot.201400200

Wakley A, Black IA (1934). An examination of the Degtiareff mathods for determining soil organic matter and a proposed modification of chromic acid titration method. Soil Science 37:29-38. http://dx.doi.org/10.1097/00010694193401000-00003

Waraich EA, Ahmed Z, Ahmad R, Yasin Ashraf M, Saifullah NV, Naeem MS, Rengel Z (2013). Camelina sativa, a climate proof crop, has high nutritive value and multiple-uses: A review. Australian Journal of Crop Science 7(10):15511559. https://www.researchgate.net/publication/286003757

Yaniv Z, Schafferman D, Zur M (1995). The effect of temperature on oil quality and yield parameters of high- and lowerucic acid Cruciferae seeds (rape and mustard). Industrial Crops and Products 3(4):247-251. https://doi.org/10.1016/0926-6690(94)00041-V

Zanetti F, Eynck C, Christou M, Krzyżaniak M, Righini D, Alexopoulou E, ... Monti A (2017). Agronomic performance and seed quality attributes of camelina (Camelina sativa L. Crantz) in multi-environment trials across Europe and Canada. Industrial Crops and Products 107:602-608. https://doi.org/10.1016/j.indcrop.2017.06.02

Zubr J (1997). Oil-seed crop: Camelina sativa. Industrial Crops and Products 6:113-119. https://doi.org/10.1016/S0926-6690(96)00203-8

Zubr J, Matthaus B (2002). Effects of growth conditions on fatty acids and tocopherols in Camelina sativa oil. Industrial Crops and Products 15(2):155-162. https://doi.org/10.1016/S0926-6690(01)00106-6 
Zubr J (2003). Qualitative variation of Camelina sativa seed from different locations. Industrial Crops and Products 17(3):161-169. https://doi.org/10.1016/S0926-6690(02)00091-2

OPEN ACCES

(c) (i)
The journal offers free, immediate, and unrestricted access to peer-reviewed research and scholarly work. Users are allowed to read, download, copy, distribute, print, search, or link to the full texts of the articles, or use them for any other lawful purpose, without asking prior permission from the publisher or the author.

License - Articles published in Notulae Botanicae Horti Agrobotanici Cluj-Napoca are Open-Access, distributed under the terms and conditions of the Creative Commons Attribution (CC BY 4.0) License. (c) Articles by the authors; UASVM, Cluj-Napoca, Romania. The journal allows the author(s) to hold the copyright/to retain publishing rights without restriction. 